\title{
Perbandingan Persepsi Pada Material - Material Upcycle Do It Yourself (DIY) Dengan Pendekatan Material Driven Design
}

Devanny Gumulya*

Program Studi Desain Produk, Fakultas Desain, Universitas Pelita Harapan

\begin{abstract}
In the past five years, technology advances and fabrication feasibility like 3D printing has boost the do it your self-movement, and it is expanding beyond products to the materials that are labelled as DIY-materials. DIY- materials are created through individual or collective through self-production practices that involve a lot of creativity and innovative approach. One of these DIY-materials is upcycle-material. The pollution on landfill and ocean has encouraged us to be more responsible for the waste we create by recycling the waste and make it as new material. Eggshells and LPDE plastic bag waste are discussed in this paper. The perception between the two DIY-materials upcycle is compared using the material driven design approach (MDD). In MDD, sensorial, interpretation, affective and performative dimensions shape people's perception and experience toward the materials. This approach is needed, to give waste material a new life and for it to be accepted on the market. Results from studies are the do and don'ts for product design process using eggshells and LDPE plastic bag waste. Imperfections through pattern, texture and colour are the qualities that people seek when interacting with DIY-upcycle materials. These qualities cannot be found in massproduced industrial made material. Design principle such as balance, contrast, emphasis, movement, pattern, rhythm, and unity/variety needs to be well planned in making pattern, texture and colour because if it is done wrong, the material will be perceived back as waste.
\end{abstract}

Keywords: perception, do it yourself, upcyle material, material driven design, design principles

$\begin{array}{ll}\text { *Devanny Gumulya } \\ \text { Email } & \text { : devanny.gumulya@uph.edu } \\ \text { Address } & : \text { Universitas Pelita Harapan } \\ & \text { Jalan Boulevard Jendral Sudirman Lippo Karawaci } \\ & \text { Tangerang, Banten }\end{array}$




\section{Perbandingan Persepsi Pada Material - Material Upcycle Do It Yourself (DIY) Dengan Pendekatan Material Driven Design \\ Devanny Gumulya}

\section{PENDAHULUAN}

Dalam konteks revolusi industri yang keempat, perkembangan teknologi informasi membuat masyarakat semakin pintar, segala sesuatu bisa dipelajari dari media internet. Salah satunya adalah tren do it your self (DIY) yang mulai menyebar dari pembuatan produk ke pembuatan material untuk produk. Perbedaan material DIY dengan material yang dibuat secara industri adalah material dibuat secara individual atau diproduksi sendiri, yang biasanya dapat berupa material baru, material modifikasi atau perkembangan baru dari material yang telah ada .

Material DIY dapat muncul juga karena kecintaan orang untuk menghasilkan sesuatu dari tangannya kembali muncul, karena dunia digital dimana segala sesuatu dibalik layar mulai melelahkan manusia. Material DIY juga didukung oleh demokratisasi teknologi, sehingga data eksperimen yang tersedia untuk diakses semua orang dan fabrikasi personal.

Pengetahuan pembuatan mateial seringkali yang didapat dari percobaan. Proses ini seringkali menghasilkan material yang diproduksi sendiri dengan mateial yang dimiliki atau limbah yang ada di lingkungan sekitar. Karena itu, proses pembuatan material dengan tangan dapat diidentifikasi sebagai proses berpikir cerdas [2]. Material DIY yang umum dibuat terbagi dua berdasarkan sumber materialnya, material DIY organik dan non organik.

Pencemaran lingkungan dan keterbatasan sumber daya alam juga mendorong perkembangan material DIY. Limbah organik dan non organik yang sudah menumpuk dimana - mana membuat kita berpikir apakah kita harus menghasilkan material yang baru? Dalam penelitian ini material yang dibandingkan persepsinya adalah limbah plastik dan cangkang telur. Menurut Badan Pusat Statistik (BPS) produksi telur di Indonesia pada tahun 2012 mengalami peningkatan dari tahun 2011 sebanyak 5,48\%. Meningkatnya produksi telur menyebabkan potensi limbah yang akan semakin meningkat dari tahun ke tahun. Apabila limbah cangkang telur tidak diolah atau dimanfaatkan akan berdampak pada kerusakan lingkungan karena limbah cangkang telur merupakan limbah organik yang membutuhkan waktu lama untuk terurai. Oleh karena itu material cangkang telur dipilih untuk di teliti.

Penelitian ini menggunakan metode material driven design (MDD) sebagai kerangka berpikir, karena metode MDD melibatkan persepsi target pengguna yang akan membantu dalam proses pengolahan material hingga review pada produk akhir.

\section{METODE PENELITIAN}

Untuk mengukur persepsi dilakukan forum group discussion pada lima sampel material terbaik dari limbah cangkang telur dan limbah kantong plastik LDPE. Dengan konten pertanyaan yang disusun dengan pendekatan MDD.

\section{Material Driven Design (MDD)}

Material merupakan hal yang penting dalam riset dan praktek dalam desain produk [3]. Dalam rangka isu global warming dan pencemaran lingkungan yang semakin meningkat, riset tentang material alternatif pengganti material yang umum dipakai juga meningkat. Penelitian tentang material umumnya dalam konteks desain umumnya 
berfokus pada bagaimana membantu desainer memilih material dalam konteks bentuk dan teknologi produksinya [4].

Dalam beberapa tahun terakhir berkembang penelitian bagaimana material membentuk pengalaman kita berinteraksi dengan sebuah produk. Dalam pemilihan material untuk menciptakan arti dari sebuah produk, terdapat beberapa faktor yang perlu diperhatikan, yaitu sifat sensoris dan teknis material, kemiripan material dan siapa pengguna atau target marketnya. Setiap faktor memiliki aspek-aspek lainnya yang juga perlu diperhatikan, misalnya untuk pengguna, terdapat aspek umur, jenis kelamin, keahlian, latar belakang budaya, dan lain sebagainya.

Setiap aspek memiliki peran yang berbeda untuk menentukan makna dari sebuah material. Material mempunyai makna tersendiri bagi penggunanya. Makna suatu material tidak selalu terlihat seperti fisik atau ciri material tersebut. Dengan adanya interaksi antara material dengan pengguna dan fungsi produk maka material yang sama bisa saja merepresentasikan makna yang berbeda dalam kondisi yang berbeda juga. Dalam arti lain, aspek tertentu yang dilihat dalam suatu benda dapat berubah tergantung dengan interaksi antara pengguna dan tujuan yang ingin diekspresikan melalui benda tersebut. Desainer harus memahami bagaimana sebuah material dapat memperoleh maknanya dan aspek-aspek apa saja yang mempengaruhi proses ini.

Faktor - faktor psikologi menjadi penting karena, dengan memahami psikologi manusia sebuah material baru dapat diterima lebih cepat. Sebagai contoh penemuan bioplastik PLA telah ada dari tahun 1890, namun baru mulai digunakan dan diterima masyarakat pada tahun 1960an. Menurut Manzini, sebuah studi sosial budaya perlu dilakukan agar sebuah material baru dapat diterima lebih baik di masyarakat tertentu [3]. Jadi dapat disimpulkan bahwa studi psikologi konsumen dan sosial budaya dimana material itu dipakai menjadi strategi untuk memperpendek proses adaptasi material baru. Tupperware menggunakan strategi ini untuk mengenalkan material plastik polyethylene dalam produk rumah tangga. Ketika pertama kali dikenalkan plastik diidentikkan dengan material yang murah, berkualitas rendah, dan banyak orang tidak puas dengan material plastik. Lalu plastik dibuat semirip mungkin dengan kayu atau kulit yang dikenal dengan faux material. Tapi plastik masih belum memiliki identitas yang kuat di masyarakat. Tupperware memperkenalkan plastik polyethylene sebagai material yang fleksibel, ringan dan lembut untuk dipegang [5]. Tupperware tidak hanya menampilkan sisi fungsional dari plastik, tapi produknya juga menawarkan pengalaman baru bagi konsumen, bagaimana ketika membuka tutup nya ada suara letupan yang khas, pengalaman sensori ini yang membedakan Tupperware dengan kompetitor lainnya. Akhirnya bila menggunakan produk Tupperware diasosiasikan sebagai ibu rumah tangga yang modern dan dapur juga berkesan modern.

Berdasarkan pengalaman sukses Tupperwear, sejak awal dekade tahun 2000, para ahli mulai merasakan pentingnya dimensi psikologi, sosial dan budaya dari sebuah material. Maka para ahli sains material mulai melakukan penelitian berkolaborasi dengan ahli desain. Dari sinilah istilah MDD mulai terbentuk.

MDD adalah sebuah pendekatan dalam proses desain, dimana semua pengambilan keputusan desain didasarkan dari keunikan karakteristik material dengan tujuan meningkatkan pengalaman pengguna ketika berinteraksi dengan sebuah produk melalui dimensi material. Tujuan dari MDD adalah untuk mendukung para desainer bahwa material bisa dijadikan inspirasi dalam proses desain selain aspek fungsi.

Berikut beberapa variable penting dalam metode MDD: 
1. Pemahaman karakteristik material oleh desainer yang didapatkan dari rangkaian eksperimen yang bersifat eksploratif. Pemahaman desainer akan karakteristik, keunikan, kelebihan dan kekurangan dari sebuah material menjadi sangat penting. Desainer harus bisa menjelaskan dengan detail perbedaan material yang baru digunakan dengan material lainnya. Hal ini baru bisa dicapai melalui rangkaian eksperiemen yang wajib dilakukan sendiri dan bersifat eksploratif mulai dari tahapan awal hingga evaluasi ketika produk digunakan. Tahap eksperimen berlangsung terus mulai dari penjumpaan pertama dengan material hingga aplikasi material pada produk. Setelah melewati tahapan eksperimen yang intens, sang desainer diharapkan dapat menjadi ahli dipengolahan material tsb dan dapat memperkirakan bagaimana material ini bereaksi pada berbagai teknik dalam proses produksi.

2. Pemahaman desainer akan data - data tentang pengolahan material yang sudah ada. Sebelum melakukan eksperimen, desainer harus benar - benar memahami penelitian, ataupun aplikasi dari material yang mau diolah yang sudah ada di pasar.

\section{Tahapan dari MDD}

Desainer produk diajarkan untuk mengikuti pendekatan sistematis untuk mengkonsepkan dan mengevaluasi ide sebelum ditranslasikan menjadi fungsi, bentuk, dan material pada desain akhirnya. Dalam MDD, proses desain tersebut dipertahankan. MDD dapat diaplikasikan ke beberapa skenario desain [1]:

\section{Skenario 1}

Desain dengan material yang umum, dan kemungkinan telah memiliki identitas sendiri, namun, desainer mencari aplikasi baru untuk mencari arti baru dan pengalaman pengguna (user experience) yang baru.

\section{Skenario 2}

Desain dengan material yang tidak terlalu umum, dimana sampel material sudah ada, namun belum memiliki identitas yang pasti. Sehingga desainer mampu mendefinisikan area aplikasi material, pengalaman pengguna, identitas, serta arti material

3. Skenario 3

Desain dengan material yang masih dalam tahap pengembangan, dimana propertinya masih belum dapat dipastikan dan mampu berkembang sesuai arahan yang diajukan desainer. Disini desainer berperan untuk mengajukan percobaan aplikasi material serta arti dan identitas yang mungkin menetap pada material.

\section{Tahap 1: Memahami properti teknis material dan karakteristik pengalaman material}

Tahap pertama dari MDD adalah pengertian akan material ini. Pada tahap ini desainer bertugas untuk lebih mengerti mengenai material yang ingin diriset lebih mendalam. Memahami material dalam kondisi sebelum diolah. Untuk mengetahui dan memahami material lebih dalam maka dapat dilakukan eksperimen pribadi terhadap material, serta melihat standar - standar yang sudah ada dsb. Terdapat 2 kategori hasil riset dalam tahap pertama ini. Yang pertama adalah riset material untuk mengetahui komponen teknisnya, dan yang kedua adalah untuk mengetahui komponen pengalaman yang dialami pengguna dari material tersebut.

Komponen teknis dari material lebih memfokuskan riset terhadap material itu sendiri. Riset ini bisa dicapai dengan melakukan eksperimen terhadap material tersebut, seperti di bakar, di tarik, di banting, dan lain-lain. 
Untuk mengetahui struktur teknikal / fisik dari material tersebut, seperti seberapa kuat, seberapa tahan terhadap suhu, dan lain-lain. Di akhir eksperimen desainer harus dapat menjawab pertanyaan ini:

1. Karakter material sebelum diolah?

2. Apa kelebihan dan kekurangan material yang diriset sebelum dan sesudah diolah?

3. Material bisa diproses dengan berapa teknik? dan outputnya seperti apa ?

4. Teknologi produksi mana yang paling mudah dan cepat untuk memproses material tsb

Dalam bagian teknikal ini, material yang diriset dapat dibagi menjadi dua. Yang pertama, adalah material yang sudah pernah dikembangkan sebelumya dan material yang masih belum dikembangkan. Untuk material yang sudah dikembangkan, desainer dapat mencari data - data dengan lebih mudah dari berbagai sumber seperti, buku, internet untuk membantu dalam riset material. Sedangkan untuk material yang masih belum dikembangkan secara jauh makah data mengenai material tersebut bisa didapatkan melalui proses MDD ini. Dengan mengikuti langkah - langkah yang sudah ada dalam MDD maka desainer dapat menemukan ciri - ciri dari material melalui metode ini. Ciri - ciri material ini dianalisa yang mana sebagai kelebihan dan kekurangan material, dan bagaimana hal tersebut mempengaruhi tujuan desain.

Yang kedua, adalah eksperimen pengalaman sensori dari material. Komponen pengalaman ini lebih berhubungan dengan bagaimana user berinteraksi dengan material yang diriset. Data ini bisa didapatkan melalui focus group discussion dimana mereka ditanyai pendapat mengenai material yang diriset. Kualitas pengalaman dari material dapat dianalisa dalam 4 level [1] yaitu:

1. Sensorial

Sensorial berhubungan dengan indera manusia seperti pendengaran, penglihatan, perabaan, penciuman dan perasa. Melaui pengukuran sensorial kita dapat mengetahui hasil dari interaksi material dengan pengguna, contoh: apakah gatal saat dipegang, apakah memiliki bau, dan lain sebagainya

2. Interpretasi (makna)

Interpretasi berhubungan dengan apa arti yang dapatkan dari material yang diriset. Apa yang didapatkan saat melihat material tersebut, ex: material tersebut memiliki bentuk yang aneh.

3. Afektif (emosi)

Afektif berhubungan dengan apa yang dirasakan pengguna saat melihat material tersebut

4. Performatif (aksi dan performa).

Performatif lebih berhubungan dengan aksi apa yang dihasilkan saat melihat material tersebut, apakah material tersebut membuat user ingin memegangnya atau menciumnya.

Bahan material yang diriset yang perlu dipersiapkan untuk FGD, harus memenuhi kriteria yang sesuai dengan 4 level ini yaitu: sampel material dengan bentuk - bentuk yang bervariasi misalnya bersudut runcing, tumpul, berbentuk geometris, serta abstrak. Kualitas sensorial yang berbeda - beda, seperti kasar, halus, kaku, elastik, dan beberapa material pendukung bila material yang diriset ternyata butuh dikombiniasikan dengan material lainnnya. Material pendukung bisa memberi kesan kontras ataupun pelengkap di keempat level pengalaman sensori.

Keempat level pengalaman ini dapat ditanyakan melalui rangkaian pertanyaan sebagai berikut:

Sensorial :

- Keunikan dimensi sensorial apa yang dimiliki material yang diriset ?

- Dimensi sensorial apa yang paling dan tidak disukai dari material yang diriset? 
- Apakah ada material lain yang mirip secara estetika dengan material yang diriset?

Interpretasi:

- Deskripsikan dalam kalimat sederhana, material ini?

- Makna apa yang muncul dibenak pengguna ketika melihat material ini?

Afektif:

- Rasa emosi apa yang dirasakan pengguna ketika melihat material yang diriset? (terkejut, saying, benci, rileks, dan seterusnya)

Performatif:

- Amati bagaimana pengguna berinteraksi dan bersikap dengan material yang diriset

Data - data FGD disarankan dirampung dalam bentuk mindmap, sehingga data - data yang relevan secara makna, emosi, sensorial, performa dapat langsung dihubungkan. Dari mindmap ini desainer dapat menarik kesimpulan mau menggunakan makna yang diidentifikasikan pengguna, memodifikasi makna yang sudah ada atau menkonstruksikan makna baru.

\section{Tahap 2. Membentuk Visi Pengalaman Material Kepada Pengguna}

Pada tahap ini, desainer mevisikan bagaimana peran material berkontribusi pada perfomansi sebuah produk dan menciptakan pengalaman sensorial yang unik ke pengguna; dan bagaimana material juga mempengaruhi hubungan antara produk yang satu dengan lain, orang lain dan dalam konteks penempatan yang berbeda. Selain data dari FGD, desainer juga diharuskan mencari studi - studi material yang diriset dan studi peran material bagi pengguna yang sudah ada sebelumnya. Bila material yang diriset benar - benar baru maka studi dapat dilakukan dengan membandingkan dengan material yang sejenis/mirip sehingga mendapatkan data yang dapat merefleksikan material tersebut.

Dengan mengetahui data pemaknaan material yang sudah ada dan yang baru, desainer baru bisa mulai membentuk visi pengalaman sensori material: bagaimana material tersebut ingin dilihat oleh user/masyarakat dan bagaimana user/masyarakat ingin mengintrepetasikan material tersebut. Desainer harus bisa mengetahui struktur material yang diriset dan visi apa yang cocok untuk dilihat oleh user, contoh: material yang bersudut dan memiliki warna turunan hitam tidak akan mungkin terlihat lucu.

Desainer harus bisa melihat apakah dampak dari material yang diriset kepada user/ masyarakat dan apa yang terjadi jika diaplikasikan terhadap sebuah produk, apakah material tersebut aman untuk dipakai sehari - hari, apakah material tersebut menghasilkan limbah? Jika ya apakah limbah tersebut dapat di daur ulang? Ini bisa didapatkan melalui studi pengguna dan perbandingan yang solusi yang sudah ada.

Ada beberapa pertanyaan yang dapat membantu desainer membentuk visi pengalaman sensori material:

Sensorial:

- Indra mana yang paling digunakan pengguna ketika berinteraksi dengan material yang diriset?

- Bagaimana orang akan berinteraksi dengan material dalam konteks yang ditentukan? 
Interpretasi:

- Bayangan apa yang ada di benak pengguna ketika melihat material yang diriset, deskripsikan?

- Apa keunikan teknis dan impresi dari material yang di riset yang perlu ditekankan di aplikasi produk final?

- Dalam konteks aplikasi apa material tersebut dapat melakukan perubahan yang positif?

- Kontribusi unik apa yang bisa diberikan material yang diriset?

Afektif:

- Rasa emosi apa yang dirasakan pengguna ketika melihat material yang diriset? (senang, sedih, takut, jijik, dan seterusnya)

Performatif:

- Kira - kira material ini memberi kesan yang berkaitan dengan pekerjaan apa?

- Kira - kira material yang diriset cocok ditempatkan dalam konteks apa?

Dengan menjawab pertanyaan - pertanyaan ini, maka visi pengalaman sensori material yang diriset dapat dibentuk pelan - pelan ke pengguna pada keempat level. Sebuah produk dapat menimbulkan lima tipe emosi pada seseorang:

1. Instrumental (kekecewaan dan kepuasan)

2. Estetis (jijik dan tertarik)

3. Sosial (menghindar dan terkagum)

4. Kejutan (terkejut dan keheranan)

5. Minat (bosan dan terpesona)

\section{Tahap 3 Membentuk Pola Pengalaman Material}

Di tahap ini desainer membentuk pola pengalaman material dengan kreativitas dan imajinasinya sebagai desainer; bagaimana menghubungkan hasil riset teknis material, hasil FGD pengalaman pengguna pada material dan aplikasi produknya. Pada tahap ini desainer sudah harus membentuk satu kata kunci untuk konsep produknya yang merepresentasikan hubungan dimensi teknis, pengalaman dan produk aplikasi seperti feminine, high tech, dan seterusnya.

\section{Tahap 4 Ideasi Konsep Produk}

Pada tahap ini, desainer merampungkan semua temuannya sebagai inspirasi dalam membentuk konsep desain. Dalam skenario material yang sudah ada dan belum umum konsep dapat dibentuk dari merubah kualitas sensorial material, misalnya tekstur, bentuk, dan teknologi produksi yang berbeda dari sebelumnya. Bila skenario material yang dalam tahap perkembangan, desainer dapat memainkan komposisi material penyusunnya, sehingga dapaat memberikan impresi pengalaman yang divisikan di tahap 3 . 


\section{HASIL DAN ANALISA}

Pada artikel ini akan lebih dibahas persepsi orang pada material limbah cangkang telur dan limbah kantong plastik LDPE, jadi proses eksperimen pengolahan limbah tidak akan dibahas disini. Sampel material yang diujikan adalah material yang sudah diproses menjadi lebih kuat dan indah. Proses pengolahan limbah berdasarkan hasil studi literatur dan eksperimen pribadi.

Tabel 1 Lima sampel limbah cangkang telur yang sudah diolah

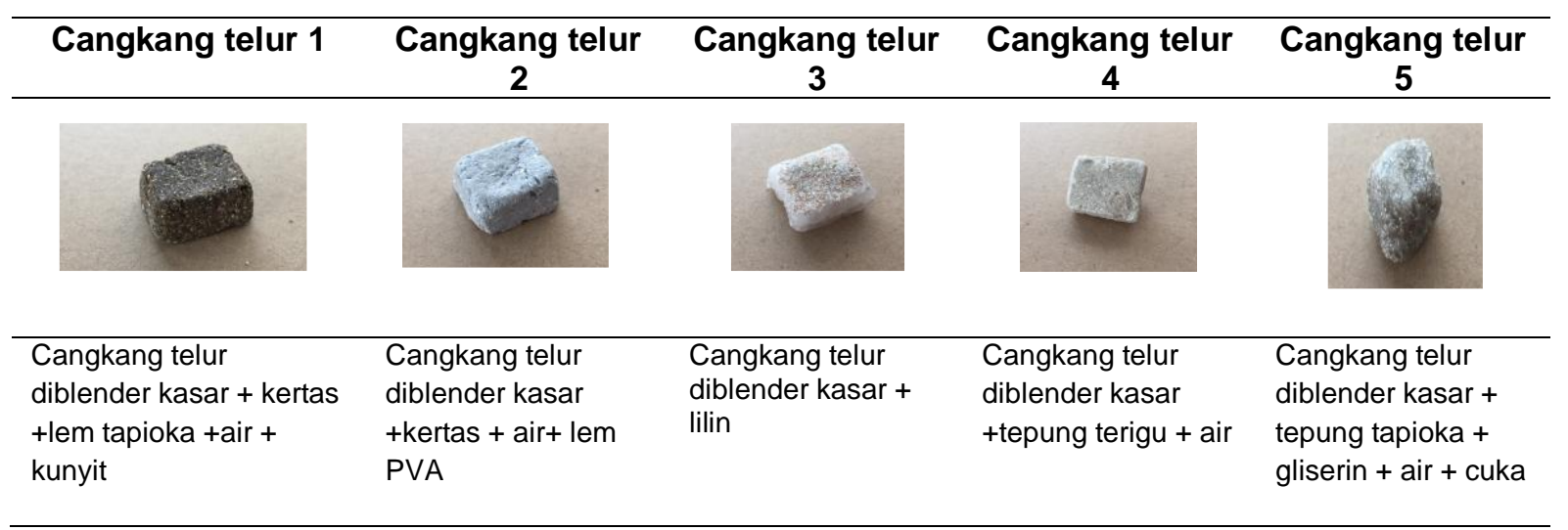

Tabel 2 Lima sampel kantong plastik LDPE yang sudah diolah

\begin{tabular}{lllll}
\hline $\begin{array}{c}\text { Kantong Plastik } \\
\text { LDPE }\end{array}$ & $\begin{array}{c}\text { Kantong Plastik } \\
\text { LDPE 2 }\end{array}$ & $\begin{array}{c}\text { Kantong Plastik } \\
\text { LDPE 3 }\end{array}$ & $\begin{array}{c}\text { Kantong Plastik } \\
\text { LDPE 4 }\end{array}$ & $\begin{array}{c}\text { Kantong Plastik } \\
\text { LDPE } 5\end{array}$ \\
\hline
\end{tabular}


Pengenalan material secara pengalaman melalui FGD (Focus Group Discussion) yang dilakukan terhadap 15 orang baik laki-laki maupun perempuan dari berbagai rentang usia dari 18- 40 tahun dengan profesi mahasiswa dan staf. Sampel material diuji dalam empat tahapan/level, yaitu sensorial, interpretative, affective dan performative. Berikut bagan hasil FGD untuk Experiential Qualities:

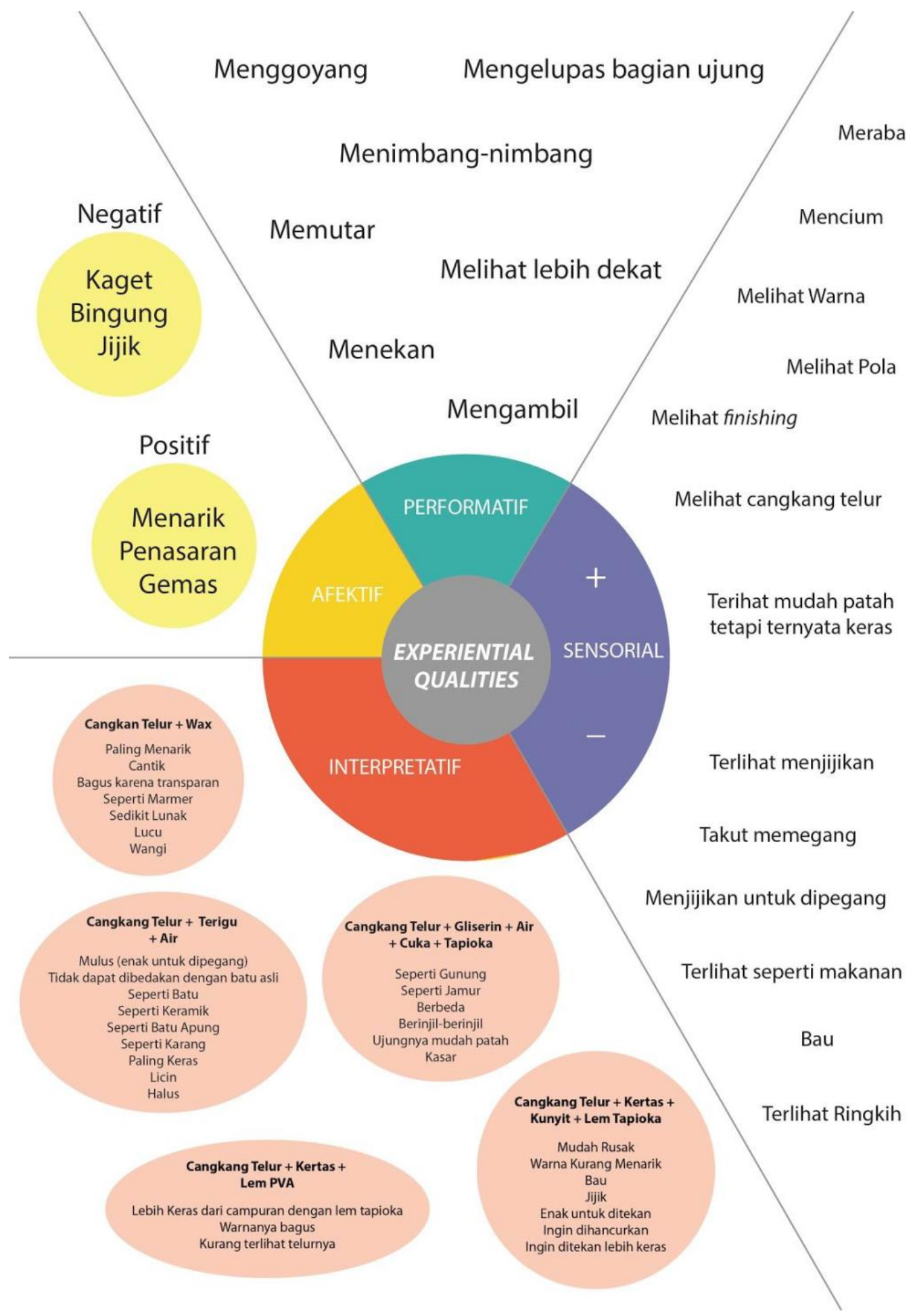

Gambar 1 Hasil respon FGD terhadap material limbah cangkang telur 


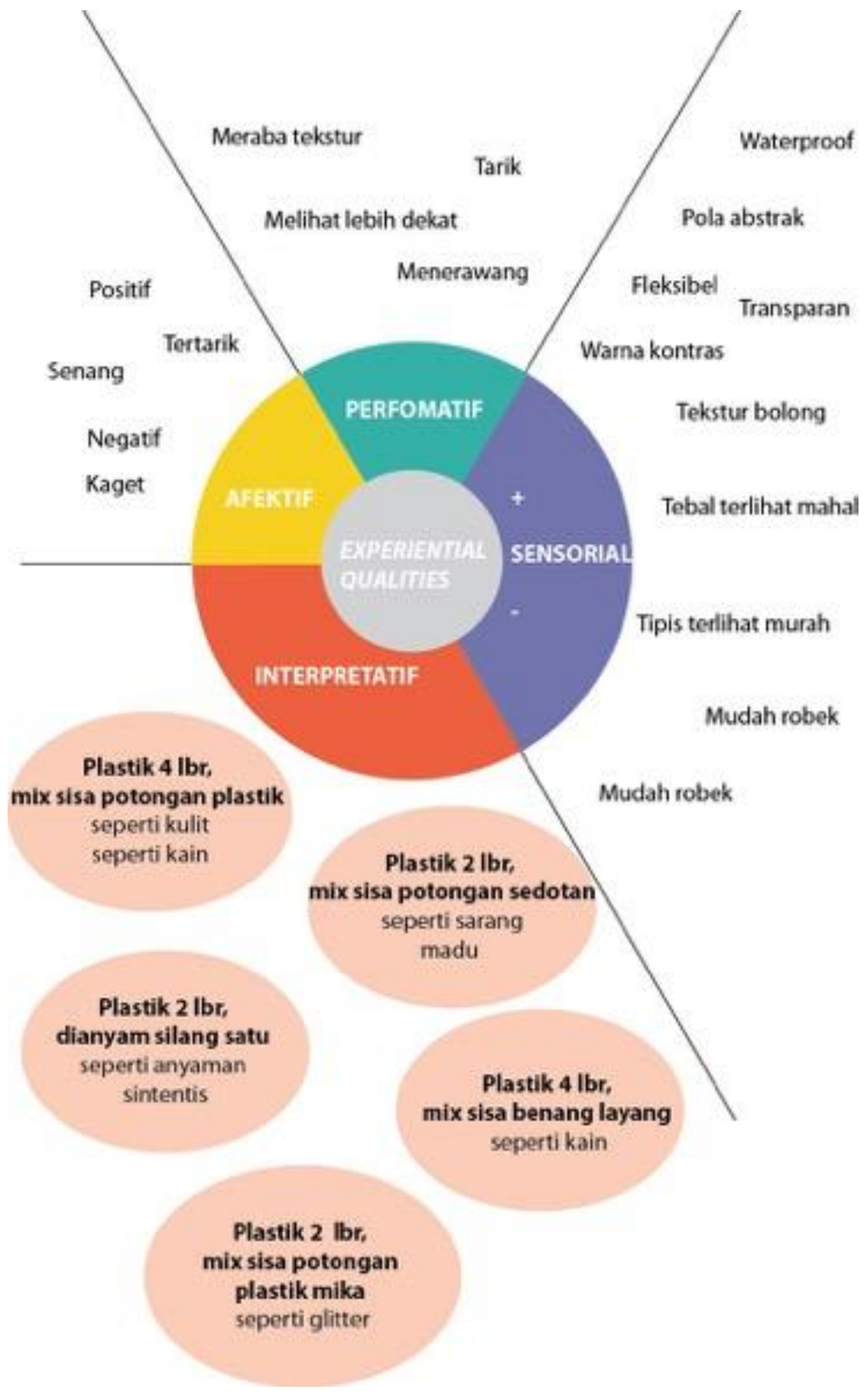

Gambar 2 Hasil respon FGD terhadap material limbah kantong plastik LDPE 


\section{ANALISA}

Tabel 3 Persamaan dan perbedaan persepsi responden

\begin{tabular}{|c|c|c|c|}
\hline \multicolumn{2}{|c|}{ SENSORIAL } & \multicolumn{2}{|c|}{ INTERPRETASI } \\
\hline Persamaan & Perbedaan & Persamaan & Perbedaan \\
\hline \multirow[t]{2}{*}{$\begin{array}{l}\text { Tekstur } \\
\text { Pola } \\
\text { Warna }\end{array}$} & $\begin{array}{c}\text { Dalam plastik presepsi } \\
\text { responden dipengaruhi } \\
\text { tebal tipisnya sampel } \\
\text { Pada cangkang telur } \\
\text { melihat keras } \\
\text { lembutnya sampel }\end{array}$ & $\begin{array}{l}\text { Hampir sebagian besar } \\
\text { responden tidak bisa } \\
\text { mengasosiasikan } \\
\text { material sampel dengan } \\
\text { material awalnya. }\end{array}$ & $\begin{array}{l}\text { Limbah cangkang telur } \\
\text { masih bisa dikenali } \\
\text { sebagai material alam, } \\
\text { karena interpretasi } \\
\text { mereka seperti batu, } \\
\text { keramik, karang, batu } \\
\text { apung. }\end{array}$ \\
\hline & material & & $\begin{array}{l}\text { Limbah plastik LDPE } \\
\text { dikenali seperti material } \\
\text { sintentis kulit dan kain }\end{array}$ \\
\hline \multicolumn{2}{|c|}{ AFEKTIF } & \multicolumn{2}{|c|}{$\begin{array}{c}\text { PERFORMATIF } \\
\end{array}$} \\
\hline \multirow[t]{2}{*}{$\begin{array}{c}\text { Tertarik } \\
\text { Kaget }\end{array}$} & $\begin{array}{l}\text { Perasaan negatif dari } \\
\text { limbah cangkang telur: } \\
\text { jijik }\end{array}$ & $\begin{array}{l}\text { Merasakan tekstur dari } \\
\text { material }\end{array}$ & $\begin{array}{l}\text { Sifat transparan plastik } \\
\text { tetap dicari responden, } \\
\text { karena mereka }\end{array}$ \\
\hline & $\begin{array}{l}\text { Limbah kantong plastik } \\
\text { LDPE: murah }\end{array}$ & $\begin{array}{l}\text { Memberi gaya tekan } \\
\text { pada material seperti } \\
\text { menarik, menekan. }\end{array}$ & menerawang. \\
\hline
\end{tabular}

Dari perbandingan ini dapat direkomendasikan beberapa hal:

1. Ketika responden berhadapan dengan material DIY yang belum mereka temui sebelumnya, indra penglihatan, peraba dan pencium yang paling berperan membentuk pengalaman mereka.

2. Kualitas sensorial yang dicari responden ketika melihat material DIY adalah ketidaksempurnaan material tersebut dari segi tekstur, pola dan warna. Ekspektasi ini sangatlah logis karena material industri dibuat sesempurna mungkin, tidak boleh ada yang bercacat. Jadi yang dicari dari material diy adalah kontrasnya dari mateial hasil buatan industri.

3. Sifat mendasar dari material yang positif, walaupun material sudah diolah sedemikian rupa dan tidak dikenali material asalnya masih dicari responden, seperti sifat transparan dari plastik.

4. Karena material DIY ini belum pernah dilihat sebelumya, ada baiknya produk aplikasi didekatkan dengan interpretasi responden, yaitu material cangkang telur seperti batu alam, jadi produk aplikasinya bisa berupa keramik. Limbah kantong plastik LDPE seperti kulit dan kain, produk aplikasinya bisa sangat luas mulai dari dari tas hingga lampu. Dengan memanfaatkan kedekatan ini, material diy lebih mudah diterima.

5. Kualitas yang perlu dihindari dari material DIY adalah jijik dan murah. Tekstur, pola dan warna harus diatur sedemikian rupa agar kedua persepsi ini dapat dihindarkan.

6. Kemampuan sensorial dan pengalaman responden dengan material DIY sebelumnya membentuk kemampuan interpretasi responden, kedua hal ini membentuk kemampuan afektif dan perfomatif responden pada material DIY.

\section{KESIMPULAN}

Dari penelitian ini dapat disimpulkan bahwa konsep material driven design (MDD) membantu menganalisa persepsi menjadi lebih detail dengan membaginya dalam 
sensorial, interpretasi, afektif dan perfomatif. Diharapkan analisa ini dapat membantu desainer produk untuk mendesain dengan material DIY dari limbah, dan mengurangi pencemaran lingkungan. Material DIY dapat menjadi material alternatif dari material industri dan diaplikasikan pada aneka produk.

Kebaruan penelitian ini adalah memberikan rekomendasi strategis bagi perancangan produk dengan material DIY. Hal - hal yang perlu ditekankan dari material DIY adalah ketidaksempurnaan yang ditandakan melalui pola, tekstur dan warna. Prinsip - prinsip desain seperti balance, contrast, emphasis, movement, pattern, rhythm, and unity/variety harus direncanakan dengan baik dalam pembuatan pola, tekstur dan warna, karena bila salah material DIY dapat dipersepsikan negatif.

\section{UCAPAN TERIMAKASIH}

Penulis ingin mengucapkan terima kasih atas bantuan, bimbingan serta kerjasama dari berbagai pihak yang telah membantu dalam penyusunan karya ilmiah ini. Penulis menyampaikan terima kasih kepada :

- Dr. Martin L. Katoppo S.T, M.T.selaku Dekan Fakultas Desain Universitas Pelita Harapan

- Dr.-Ing. Ihan Martoyo, S.T., M.Sc selaku Ketua LPPM Universitas Pelita Harapan

- Artikel ini merupakan bagian dari publikasi penelitian internal UPH dengan no. No. 187/LPPM-UPH/VI/2018

\section{DAFTAR PUSTAKA}

[1]. Karana E, Barati B, and Rognoli V. 2015. Material driven design (MDD): A method to design for material experiences. International Journal of Design. 9(2):35-54.

[2]. Sennett R. 2008. The Craftsman. New Haven: Yale University Press;

[3]. Manzini E, and Petrillo A. 1991. Neolite. Metamorfosi delle plastiche. Milan: Domus Academy;

[4]. Ashby M, and Cebon D. 2007. Teaching engineering materials: The CES EduPack [Internet]. Available from:

http://web.mit.edu/course/3/3.225/refs/Teaching_Engineering_Materials.pdf [cited 2015 Jun 1]

[5]. Clemenshaw D. 1989. Design in Plastics. Beverly: Rockport Pub; 